(投稿準備中).

MAtsumoto, T. (1978): Japan and adjoining areas. In Moullade \& Nairn eds., The Phanerozoic Geology of the World II. 79-144 in 529. Elsevier, Amsterdam.

Matsumoto, T., NodA, M. \& KozAI, T. (1982): Upper Cretaceous Inoceramids from the Monobe area, Shikoku. 53-68. Palaeont. Soc. Japan Spec. Pap.,
25.

Pergament, M. A. (1966) : Zonal stratigraphy and Inoceramus of the lowermost Upper Cretaceous of the Pacific Coast of the U.S.S.R. Tr. Geol. Inst. Akad. Nauk S.S.S.R., 146.

YABE, H. (1927) : Cretaceous stratigrapy of the Japanese Islands. Sci. Rept. Tohoku Imp. Univ., 2, 11(1), 27-100.

ザイール南東部における環境変化に関する自然地理学的調査

式 正 英*

\title{
Reconaissance Geographical Study on Natural Environmental Change in the SE Region in Zaire
}

Masahide SHIKI

1983年10月 8 日より10月26日までの間，ザイー ルとベルギーとに調查旅行をした。その内ザイー ル（旧ベルギー領コンゴ）に滞留したのは10月 10 日から10月19日までの10日間であった。この調査 の費用の一部には東京地学協会科学研究補助金が あてられた。記して同協会に感謝の意を表する。

1. 調查の目的

地球的規模で生起しているのではないかと憶測 されている, 自然的, 人為的原因による環境変化 が, 早垄や飢饉となってとくにアフリカの低緯度・ 中緯度地域（サヘル地域，モザンビークなど）を 襲っていることが最近頻繁に報ぜられている。そ の実態の一部を見きわめた上で，地理学的立場か ら実情の因果関係を整理する方向ができるか，ま た地学的に関連する内容があるかを確かめること を第一の目的とした。

アフリカ各地を対象とした日本の調查研究活動 は決して少ない数ではない。自然地理学関係の調 查はケニア, ウガンダ, タンザニア, カメルーン, アルジェリアを対象に，1964年以降，矢沢大二， 戸谷 洋, 門村 浩が夫々研究代表者となって順
次実施されて来た。その他自然人類学的調査や言 語学的調查などが, 京都大学, 東京外国語大学な どの研究者を中心に行われて来ている。ザイール 東縁部, ニーラゴンゴ火山の調查には東北大学の 調查班が出掛けている。海外協力事業団, 国際建 設技術協会の地形図作成事業はケニア，タンザニ ア，ギネアの夫々一部で行なわれ，すでに印刷刊 行されている。さらにケニアでは土地利用調査も 日本の技術者によって実施され1983年度中には成 果をみる手筈である。このような状況の中で，上 記のものと重ならない研究テーマを探すことがで きるかを第二の目的と考えた。

さらに新たに本格的調査を仮定した場合の生活 条件 (政情, 交通, アコモデーション, 安全性な ぞ）や既存資料，現地の協力態勢など，可能性の 度合を検討してみることにした。以上アフリカを 主題とした研究調查活動の予察調查を意図した訳 である。

2. 調查の契機と背景

調查に赴いた場所はザイール南東部；シャバ州 ルブンバシ市（旧エリザベードビル）とその周辺

\footnotetext{
* お茶の水女子大学文教育学部地理学教室 Department of Geography, Ochanomizu University
} 
地域である。ここを選んだ理由は 国際地理学連 合 (IGU) ワーキンググループ「動態環境地図学 (Cartography of Dynamic Environment)」のシ ンポジウムが，J. アレキサンドル教授（リエージ ュ大学）がオーガナイザーとなりルブンバシ市で 10月中旬に開催されたからである。このワーキン ググループの委員長はアンドレ・ジュルノー教授 （カーン大学）であり，筆者は1980年以来メンバ 一を勤めている。テーマは「熱帯地域の環境地 図」であったが，10名ほどの外国からの出席者は 殆んど地形学を主とする自然地理学者であった。 アレキサンドル教授はかってルブンバシ大学に教 授として 12 年間勤務し, 現在も客員教授として連 年出講しており, ザイールが主な研究のフィール ドである。このシンポジウムの特徴は, 室内での 研究発表討議は 2 日間で, 残りの 8 日間は野外巡 検に向けられたことである。筆者は“A Land Use Mapping in Africa in Cooperation with Japan”をテーマに研究発表を行ない, 巡検を通 じて調查活動に従事した。

調查した地域は, ルブンバシ市域, ルイスイ シ, ビアノ台地, コルウェジ周辺, フングルメ付 近などであり，遠い所でルブンバシから $300 \mathrm{~km}$ 弱の範囲である。移動にはジープや汽車が使用さ れたが，宿泊の拠点にはルブンバシ，コルウェジ の他, 停車中の寝台車 (ビアノ台地) があてられ た。

今回の調查に関連し日本の国内でザイールの情 報を蒐めるのには, 初期の段階ではかなり困難を 感じた。しかしやがてザィールに進出している日 本企業に接触して始めて具体的にして有用な資料 を手に入れることができた。ザイール鉱山開発株 式会社は日本鉱業株式会社の子会社として設立さ れ, ザイール南東部からザンビアにまたがる世界 的コッパーベルト地帯のザイール側のムソシ，キ ンセンダ地区に鉱区を取得した。同社は1972年以 来採掘を続け, 年 3 万トンの銅精鉱を日本向けに 送り続けて来た。しかしアンゴラ内戦の影響でベ ンゲラ鉄道が使用できなくなり南ア経由で船積み されるようになってからは, 輸送費が嵩み, 結果 として業績が振わなくなり, 1983年末をもって現 地に招ける稼行経営を放棄する破目に陥った。ザ
イール鉱山は現地名をソデミザ (Sodemiza) とい う。現地事務所はルブンバシの中心部にあり, 筆 者の滞留中は引揚げ準備中ではあったが，何かと 生活上の便宜を頂いた。鉱山の盛時には日本人は 家族をふくめ600名に及んだが，1983年には技術 者を中心に40名ほどに減じていた（引揚げ後ルブ ンバシの日本人は日商岩井社員の 1 夫婦だけとな る)。その他ザイールの海岸部から浅海底にかけ ての石油関連して日本が資本参加しているザイ ール石油開発会社の事業や石川島播磨重工が施工 したコンゴ川下流のマタディ橋の完成（1983年） などに目立った日本企業の進出がみられる。

\section{3. 自然環境について}

ザイールの国土はコンゴ川（ザイール川）の流 域とほぼ一致しておりルブンバシの周辺はその最 上流域にあたり, 海抜高度は $1200 \mathrm{~m}-1500 \mathrm{~m}$ 示 す処が多い。安定陸塊アフリカ楯状地の一部で, 基盤岩は後期プレカンブリア紀クンデルング層の 石灰質片岩, 苦灰岩質片岩, 砂岩などょり成り, 一 部に陸成の白亜紀カラハリ砂岩層が分布する。プ レカンブリア末以降海進はなく, 大陸台地の地形 を基調とする。台地の表面は第三紀に形成された 準平原で平坦性はきわめてょく, 水平な地層を示 す部分が殆んどだが，局部的に古生代造山運動を うけて地層が急斜している。急斜層の部分は中起 伏の山地を形成し，山地を貫流するところで河川 は峡谷をつくる。コンゴ川源流にあたるルアラバ 川, ルフィラ川などが南から北へ流れるがこれら の川の支谷が, 上記準平原を刻んでいる台地の縁 には壮大な崖がみられる。

年降水量はルブンバシで $1229 \mathrm{~mm}$ と, 内陸とし ては比較的多く 5 月から 9 月までの間は殆んど降 雨がない。降水は11月から 3 月の間に集中する。 すなわち 1 乾季, 1 雨期の熱帯南部気候区に属す る。自然植生の極盛相は常緑広葉樹の密林ムフル (Muhulu) であり，野火や人為によりこれが破壊 された場合, 草本を主とするサバナ景観となり， 再生の過程で落葉広葉樹林ミオンボ (Miombo) となる。銅・コバルトの含有率の高い鉱石が地表 近くに露出する場合は, 森林の発達を阻害しサバ ナの状態になる。市街の周辺ではマツやモクマオ ウが植林されているし，白人の植民集落ではアカ 
シア，ジャカランダなどが移植され，巨木に成長 している。人為による植生の破壊は顕著であり, 放牧地の造成，炭焼き，狩猟・畑除草・害虫駆除 等の目的による野焼きや焼き畑などが絶え間なく 進行している。概括的にこの地域は森林景観であ るが，変化には敏感であり一時的にはサバナ景観 を呈するので，サバナ・フォレストの一種とみら れる。

\section{4. 地形景観としての蟻塚}

世界のサバナ・フォレストの地域にはしばしば テルミティエール(Terimitières) すなわち蟻塚の 見られることについては既に知られている。しか し普通東南アジア, 南アメリカ等で高さ $1 \sim 2 \mathrm{~m}$, 高いものではオーストラリアで $4.5 \mathrm{~m}$ のものが 報告されているが，とくにザイールのこの付近の ものは世界一の規模であり密度が大きい。ザイー ルの蟻塚の土量は 1 ha あたり 240 万g $\mathrm{kg}$ で面積の $30 \%$ にあり，土層を深さ $20 \mathrm{~cm}$ にわたって移動 した量に相当し，他地域の例はその10分の1以下 に過ぎない。密度はオーストラリア 1 9/ha, 中央 アジア162/ha に対し，ザィールでは500〜800/ha と桁ちがいである（土量及び密度の数字は LEE \& WOOD: Termites and Soils 1971による)。

ルブンバシからコルウェジ，ビアノ台地にかけ て調査地域のどこにでも蟻塚が卓越しているのが 見られた。規模は高さ $6 \mathrm{~m} \sim 9 \mathrm{~m}$ 位，中には $10 \mathrm{~m}$ を越すものもあり，基底の直径は $10 \mathrm{~m} \sim 20 \mathrm{~m}$ も る。ここの場合の蟻（Termites）は，ただの土壤 動物ではなく，明らかに地形々成営力であり， Bioturbation の主因となる。ルブンバシ周辺の 蟻塚は円錐形を呈するが，これは既に形成を熄め た旧いものであり，蟻塚の側面は一種の崖錐であ る。一方コルウェジ周辺の蟻塚は現在形成中であ り塔状に敢立する。時折布状洗食を受けるような 場所では， $1 \sim 4$ 年生位の新しい蟻塚群がみられ るが，高さは $0.3 \mathrm{~m}$ ，密度4500～5000/ha である。 大規模な蟻塚はこれらが集合し数百年以上を要し てつくられるものと推定される。円錐形蟻塚は 150 年ほど前に放棄されているが雨食に堪えてい
ることは注目すべきである。地表は一般にラテラ イトの盤層で硬いが，蟻塚はシルト，粘土の供給 源で煉瓦の原料となる。巨大な蟻塚群が $300 \mathrm{~km}$ 程の間で，一方が形成中一方が放棄されている原 因を解明することが環境変化の究明につながろ 亏。

5. その他の問題

ビアノ台地面は60年前に放牧地に開かれたが， それ以来ガリー侵食が盛んとなり，1回50 mm 以上の豪雨が年平均 5 回はあるが， 1 回ごとに $100 \mathrm{~m}$ という急速さで谷頭侵食が台地面を刻んで いる。また準平原上に載る古第三系のグレポリモ ルフ砂岩の岩塊には砂漠漆の痕跡が残り第三紀の 乾燥気候の証跡と考えられている。一方河谷によ る大陸台地の開析は第三紀に始まるものの，上流 部の台地の崖の形成は洪積世の気候変化に関連す ると考えられているが，未だ定説がない。つまり 氷期, 閒水期におりる付近の環境が乾燥か湿潤か いずれであったかを確定し得ていない状態であ る。

総じて調査した地域は環境変化について実に多 様な問題を内包しているとみられる。時間的尺度 を変えることにより，現在につながる数 10 年の間 の変化一—これには鉱山の経営や都市の発達，牧 場の開発が関わり，これらを無視できない——か ら, 数100年オーダーの変化一一蟻塚地域の転移, 植生の遷移がかかわる—，1000年オーダーの変 化—クライマティック・オプティマムには湿地 が多かった証拠がある—に加えて，氷期・間氷 期における気候変化，さらには第三紀における気 候変化の証跡などと, 多種多様の環境変化の課題 が充満している地域である。飢䭈状態は現在この 調查地域には見られないが，衛生上・保安上の不 確実さは捨てきれない。調査にあたりアフリカを 熟知した人々の助力は不可欠であり，独りで行動 することは不可能に近い。今回の調査にあたって は, 現地ルブンバシ大学の地形学者 $\mathrm{J}$. ソワイエ 教授に終始お世話になった。紙上を借りて深く感 謝しておきたい。 